\title{
Корисници и коришћење Дигиталне библиотеке Будве
}

\author{
Гордана Љубановић \\ Маја Симоновић \\ Јавна установа Народна библиотека Будве, Црна Гора \\ zavicajna@nbbd.me
}

\begin{abstract}
Сажетак
Народна библиотека Будве је 2018. одлучила да започне изградњу дигиталне библиотеке са жељом да прошири постојећу понуду онлајн услуга и да уважи потребе савремене публике која све више користи дигиталне садржаје. Неко вријеме након покретања Дигиталне библиотеке Будве, природно су се поставила питања дјелотворности уложених ресурса и даљих праваца развоја која траже чињеничне одговоре. Иако су постављени садржаји завичајног профила, претпоставка је била да ће нови канал презентовања привући публику изван локалних географских оквира, што је анализа једногодишњег коришћења и корисника Дигиталне библиотеке потврдила. Потврћено је и искуствено запажање да њена посјећеност директно корелира са видљивошћу у медијима и на друштвеним мрежама. За анализу промета коришћене су квантитативне статистичке методе које нуди Гугл аналитика.

Изложена анализа корисника и образаца коришћења Дигиталне библиотеке Будве даје слику само у основним цртама. Ипак, то је први покушај неке црногорске библиотеке да једно поље свог дјеловања обради и представи језиком и методама савремене вебометрије и библиотечке статистике.

Кључне речи: Народна библиотека Будве, Дигитална библиотека Будве, дигиталне библиотеке, онлајн библиотечке услуге, квантитативна истраживања, статистичка анализа корисника, статистичка анализа коришћења, Гугл аналитика, вебометрија, друштвене мреже
\end{abstract}

\section{Увод}

Као многе јавне библиотеке у нашим крајевима, и будванска је основана послије Другог свјетског рата, 1946. године. Данас ради у два простора, у Будви и Петровцу, располаже фондом од око 60.000 књига и просјечно годишње има око 1500 регистрованих корисника, што чини 6,8 процената становништва општине. ${ }^{1}$

Приморски градић Будва има дугу историју сакупљања књига у приватним, манастирским и јавним збиркама и читаоницама разних друштава. ${ }^{2}$ Међутим, стицајем различитих околности, у фондовима данашње Народне библиотеке Будве недостају стара издања и оригинална дјела аутора из овог града и са територије будванске општине. Одлука да се започне са изградњом дигиталне библиотеке проистекла је из жеље да се постојећа онлајн понуда - онлајн јавни каталог (Online Public Access Catalogue - OPAC) који нуди библиографске информације, допуни понудом примарних документационих извора завичајне провинијенције те из спознаје да савремена публика све више користи дигиталне садржаје и да би Библиотека требало да уважи њене потребе и навике. Дигитална платформа на адреси https://digital.nbbd.me отворена је за јавност крајем 2019.

\footnotetext{
1 Више података о историјату и актуелном раду Библиотеке може се наћи на Народна библиотека Будве, преузето 21. 12. 2020, https://www.nbbd.me.

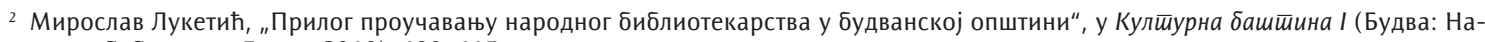
родна библиотека Будве, 2019), 409-415.
} 
У духу демократске традиције јавних библиотека и савременог покрета за отворени приступ, сви садржаји су јавно доступни са дозволама за фер/поновно коришћење, осим за мањи број јединица гдје је оригинални власник дефинисао извјесна ограничења слободе коришћења.

Циљ овог рада је да се коришћењем података из дневника посјета (log files), статистичким алатима Гугл аналитике освијетли профил корисника и квантитативно представи коришћење понуђених дигиталних садржаја током прве цијеле године рада Дигиталне библиотеке Будве. Уочени трендови ће се користити за дефинисање генералних смјерница политике развоја ДББ.

\section{Организација Дигиталне библиотеке Будве (ДББ)}

Изградња структуре ДББ је планирана као фазни процес током којег се постепено додају модули за различите врсте грађе и повећава број могућности у оквиру основних функција: претраживања, прегледања и преузимања. У овом, почетном издању, ДББ садржи претежно текстуалну грађу која се дијели у четири основне врсте - групе: Књиге, Новине и часописи, Рукописи и Плакати. ${ }^{3}$

У корисничком дијелу, садржаји су груписани према два основна критеријума: врсти грађе и географској области са којом су повезани, уз посебне тематске колекције. Све јединице примарно припадају некој врсти грађе, а на другом нивоу се приказују у скуповима, према припадности колекцији или географској области. То значи, на примјер, да ће се плакати са библиотечке изложбе „Будвански крај у Првом свјетском рату“ појавити у збиркама „Плакати“, "Издања Библиотеке“ и „Будва“ (географска скупина).

У техничком смислу, ријеч је о документно оријентисаној NoSQL бази података MongoDB. За приказ се користи Angular framework, а за обраду података и комуникацију са базом ExpressJS framework базиран на технологији NodeJS. Одабране технологије омогућавају адекватан приказ и истовремено представљају добру основу за смештање и обраду садржаја из дигиталних колекција.

\section{Корисници и коришћење - анализа и резултати}

Без великог и циљаног публицитета, ДББ је нашла своје мјесто на културној мапи града, Црне Горе и шире. О томе говоре подаци из дневника посјета који су бројчани и, самим тим, мјерљиви, упоредиви и погодни за анализу.

У Одјељењу завичајне збирке подаци са Гугл аналитике се прате од 1. новембра 2019. У раду је спроведена анализа ових података за 2020, прву цијелу годину рада. Њоме је обухваћен период од 1. јануара до 27. децембра 2020. Предмет испитивања је анализа промета, а користе се статистичке методе истраживања које нуди софтверско рјешење Гугл аналитика. ${ }^{4}$ Обављена испитивања дају увид у то ко користи садржај ДББ, које се јединице користе, из којих разлога и у којим ситуацијама. При томе се подаци илуструју графиконима и таблицама, анализирају упоредо и изводе закључци о трајању, начину и квалитету коришћења.

Циљ анализе је да се добије јасан увид у структуру, интересовања и понашање корисника те размотре опције за постизање свих до сада дефинисаних циљева - повећање броја корисника, стицање редовних, продужење трајања сесија са ДББ, повећање броја преузимања дигиталних јединица.

\footnotetext{
3 Детаљније представљање конструкције, збирки и појединачних дјела у дББ може се прочитати у е-часопису Шквер: Гордана Љубановић и Маја Симоновић, „Дигитална Народна библиотека Будве“, Шквер 4 (2020), 5 (2021, у припреми), преузето 20.1. 2021. http://skvermagazin.me/.

4 За упознавање са Гугл аналитиком коришћено је више онлајн публикација и извора, на примјер: Google Analytics Academy, preuzeto 20. 12. 2020, https://analytics.google.com/analytics/academy/course/6.
} 
Осим праћења активности веб-мјеста у реалном времену, три основна сегмента извјештаја Гугл аналитике су: праћење састава и поријекла корисника/јединствених посјетилаца (Audience), затим аквизиција (Aquisition), која се бави цјелокупним саобраћајем на веб-мјесту и, за предвиђање и планирање будућег саобраћаја можда најважније, понашање посјетилаца (Behaviour).

\section{Корисници}

Овај сегмент садржи податке о броју, врстама посјетилаца и њиховим карактеристикама у смислу демографских особина и географске локације, коју би требало схватити условно, јер није ријеч о локацији физичких лица, него њихове адресе интернет протокола (IPaddress).

Укупан број јединствених посјетилаца у 2020. години износи 576. Из табела које слиједе види се да је већина, њих 336 (58,23\%), са сервера из Црне Горе, као и највећи број посјета (сесија). Ово је очекиван исход ако се узме у обзир завичајност садржаја. Првих пет мјеста у погледу посјетилаца и броја посјета је идентично, осим што се Сједињене Америчке Државе (САД) и Србија смјењују на другом и трећем мјесту по броју посјетилаца, односно посјета.

\begin{tabular}{|l|l|l|l|}
\hline Земља & $\begin{array}{l}\text { Корисници: број } \\
\text { (проценат) }\end{array}$ & Земља & Сесије: број (проценат) \\
\hline Црна Гора & $336(58,23 \%)$ & Црна Гора $(62,00 \%)$ \\
\hline САД & $101(17,50 \%)$ & $224(20,36 \%)$ \\
\hline Србија & $69(11,96 \%)$ & Србија & $101(9,18 \%)$ \\
\hline Кина & $18(3,12 \%)$ & САД & $18(1,64 \%)$ \\
\hline Босна и Херцеговина & $9(1,56 \%)$ & Кина & $10(0,99 \%)$ \\
\hline Словенија & $4(0,69 \%)$ & Босна и Херцеговина & $4(0,36 \%)$ \\
\hline Велика Британија & $3(0,52 \%)$ & Велика Британија & $4(0,36 \%)$ \\
\hline Јапан & $3(0,52 \%)$ & Русија & $4(0,36 \%)$ \\
\hline Русија & $3(0,52 \%)$ & Шведска & $4(0,36 \%)$ \\
\hline Шведска & $3(0,52 \%)$ & Словенија & $3(0,27 \%)$ \\
\hline Остале земље & $27(4,86 \%)$ & Аустрија & $65(5,90 \%)$ \\
\hline Укупно: & 576 & Остале земље & 1.100 \\
\hline
\end{tabular}

Табела 1

Проценат нових корисника у протеклој години је $87,37 \%$ и то јесте један од показатеља успјешности, нарочито у свјетлу чињенице да је ова дигитална библиотека релативно нова. Међутим, код веб-мјеста са великом количином страница које захтијевају читање и служе истраживачком раду, обраћа се пажња и на проценат корисника који се враћају. У случају ДББ то је 12,63\%. У будућности, повећање броја посјетилаца који учестало користе услуге значило би да су у претходним посјетама успјели да пронађу тражену грађу те да Дигиталну библиотеку користе као познат и задовољавајућ извор информација. Стога ће се овом податку редовно посвећивати посебна пажња.

Демографски састав корисника - одређен на основу података које уносе у обрасце за креирање налога на Гуглу - показује готово подједнаку заступљеност припадника мушког и женског пола, с тим да су мушкарци у благој предности (54,45\%). Што се тиче узраста посјетилаца, из табеле бр. 2 је јасно да су корисници у претежном броју $(61,00 \%)$ припадници студентске и млађе радно активне популације. Ово је очекивано јер је то информатички и информационо писменији и активнији дио становништва. Проценат корисника старијих од 55, па и 65 година 
је значајно мањи (по 5,50\%). То, с једне стране чуди, у години у којој је старијој популацији било ограничено слободно кретање и коришћење библиотеке током читавог једног квартала, али је с друге стране очекивано јер су њој дигитални медији мање блиски.

\begin{tabular}{|l|l|}
\hline Проценат укупног броја & Узраст посјетилаца \\
\hline $27,50 \%$ & $18-24$ \\
$33,50 \%$ & $25-34$ \\
\hline $15,50 \%$ & $35-44$ \\
$12,50 \%$ & $45-54$ \\
$5,50 \%$ & $55-64$ \\
$5,50 \%$ & $65+$ \\
\hline
\end{tabular}

Табела 2

У сегменту Аквизиције софтвер сам нуди, као примарну, анализу канала путем којих корисници долазе на веб-мјесто. Од 576 јединствених посјетилаца, путем друштвених мрежа (Social) дошло је 287 корисника (49,83\%). Даље, прави се разлика између органског (Organic search) и директног претраживања (Direct search), гдје први начин подразумијева долазак преко неке машине за претраживање, док се као директно претраживање биљежи искључиво посјета путем уписивања веб-адресе у адресну траку. Мјери се и референтни промет (Refferal), то јест, посјета са веза (линкова) на другим сајтовима. ДББ путем органског претраживања има 100 посјетилаца (17,29\%), путем директног - $153(26,61 \%)$, док референтног промета има 36 $(6,27 \%)$. Ови подаци указују да је присуство на друштвеним мрежама и у медијима итекако битно за промет на веб-мјесту, што ће се потврдити и анализом података о понашању корисника. Такође, мали референтни промет указује да би требало повећати присуство на другим, сродним или пријатељским, веб-мјестима. То подразумијева сарадничке договоре на нивоу управе са другим институцијама културе и медијима из области културе, образовања и науке, као и узајамност, то јест, постављање путања ка тим мјестима на сопственом веб-мјесту.

Уколико се упореди анализа канала и врсте уређаја са којих посјетиоци улазе на ДББ, очигледна је повезаност мобилних телефона и друштвених мрежа. Чак 64,76\% укупног саобраћаја потиче са мобилног телефона. Оволики постотак указује на то да је он доминантан уређај за приступ, иако алати за кретање по Дигиталној библиотеци и њено коришћење у пуном потенцијалу не могу на овај начин адекватно доћи до изражаја. Због тога је очекивано да ова анализа, кад јој се додају и подаци о просјечном трајању сесије, покаже да корисници не проводе на сајту ДББ вријеме које би било неопходно за удубљено читање или истраживање. Са десктопа $(33,68 \%)$ и таблета $(1,56 \%)$, који су погоднији за ову врсту коришћења, проценат корисника је мањи, али се запажа пораст просјечног трајања сесије код посјетилаца који користе десктоп рачунаре.

\section{Kоришћење}

Из угла институције која покреће и одржава једну дигиталну библиотеку, најкориснији сегмент Гугл аналитике је дио који се бави понашањем корисника: број посјета, број сесија, просјечан број страница по сесији, укупно проведено вријеме (трајање сесије) и вријеме проведено на страници.

Из прегледа на Слици 1 уочљиво је да највише прегледа има приступна страница (Нотераge). Од укупно 2238 прегледа страница, почетна биљежи 547.

Изузетно је висока стопа посјете само једној страници: 75,37\%, а просјечно вријеме проведено на њој износи 2 минута и 53 секунде. Ови се подаци нарочито истичу при упоређивању 


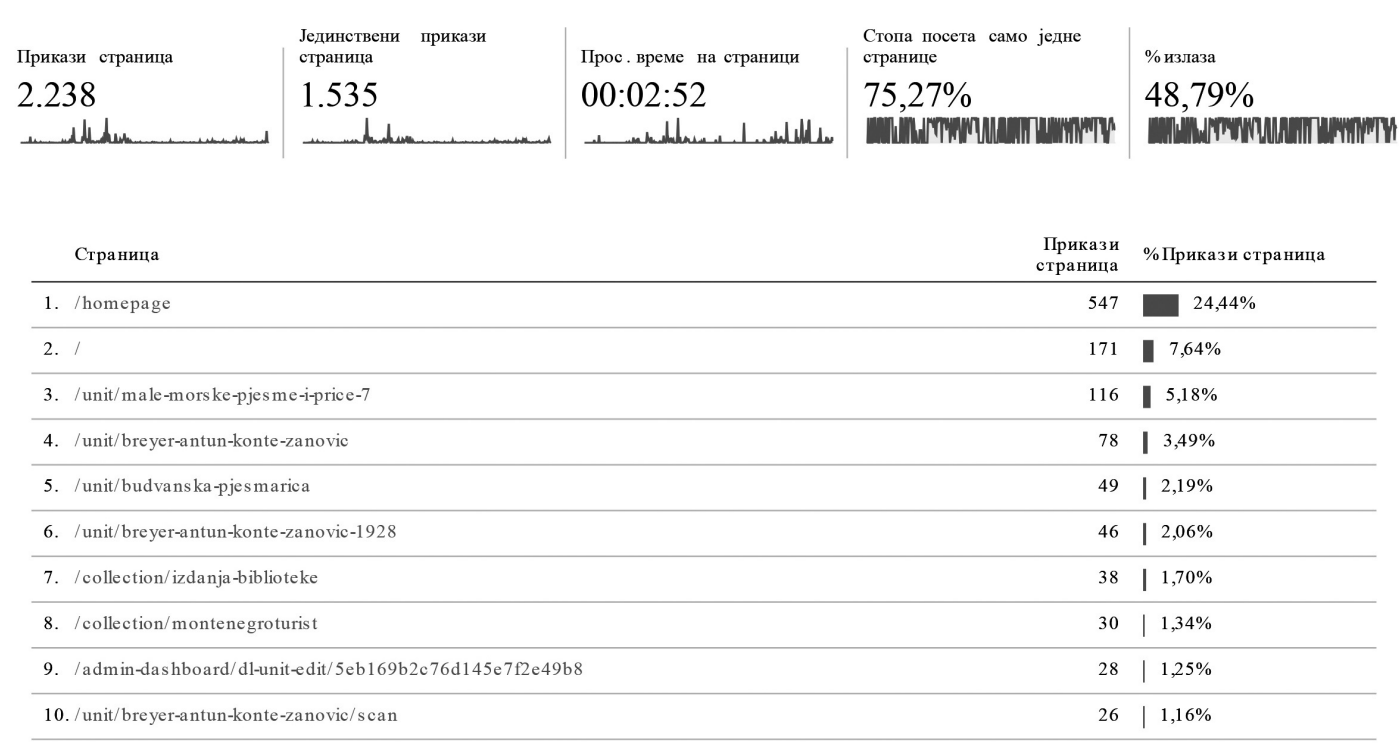

Слика 1

локацијских података корисника: САД се налазе на другом мјесту по броју корисника (101), али је стопа посјете само једној страници 100\%, што резултира ниским просјеком трајања сесије. Србија, која је трећа по реду у погледу броја корисника (69), биљежи 224 сесије. Не само да је њихов број у порасту, већ је просјечно трајање једне интеракције корисника из Србије 8 минута и 33 секунде, из чега произилази да, у просјеку, ови корисници проводе највише времена на страницама Дигиталне библиотеке. На графикону који слиједи види се да је њихов број у континуираном порасту, иако малом, а расте и број сесија, чије је трајање такође у благом порасту, али још недовољно за квалитетно коришћење ДББ у традиционалном смислу, ако се тако може назвати читање и прегледање страница. То поткрепљује тезу, доказану у више иностраних истраживања, да су савремени корисници склонији листању, дијагоналном читању и, евентуално, "понашању хрчка“ (масивном преузимању за касније - неизвјесно - читање), него студиозном и концентрисаном коришћењу понућених извора информација. 5 Пошто није реално очекивати да ће корисници преко ноћи промијенити своје обрасце понашања, један од начина да се повећа посјета јесте да се унесе више сликовних и аудио-визуелних садржаја.

С друге стране, дигиталне библиотеке током времена граде солидну базу дугорочних корисника - истраживача тако што повећавају количину грађе и константно промовишу базу и њене садржаје кроз канале стручне и научне комуникације.

Такође, уколико би се у наредном периоду у подешавања Гугл аналитике и саме Дигиталне библиотеке поставиле опције за праћење и бројање радњи у оквиру појединачних страница: преузимања дигиталних јединица и преузимања цитата - то би дало вјеродостојнију слику о активностима корисника. Тим прије ако се узме у обзир чињеница да је већина посјета са мобилних телефона који нису погодни за читање, али имају могућност преузимања и складиштења јединица те њиховог прослијеђивања на друге уређаје.

Просјечно вријеме трајања сесије и просјечно вријеме проведено на једној страници трају приближно исто: корисници се на страници задржавају у просјеку 2 минута и 53 секунде, док једна сесија (која обично траје дуже јер обухвата читаву активност током једне посјете,

\footnotetext{
${ }^{5}$ На примјер, чланак у часопису ASLIB износи резултате истраживања које су наручили Британска библиотека и ISC (Заједничка комисија за информационе системе; тијело британске владе за примјену информационих система у високом образовању и научно-истраживачком раду): I. Rowlands et al., "The Google generation: the information behaviour of the researcher of the future." Aslib Proceedings 60 (2008): 290-310.
} 
укључујући преласке међу страницама) траје 3 минута и 1 секунду. На чињеницу да је трајање једне сесије у просјеку скоро једнако времену проведеном на страници утиче резултат дијељења који се добија тако што се укупно вријеме дијели са укупним бројем посјета. Гугл аналитика у овом дијелу има озбиљан недостатак: ако посјетилац изађе са странице кликом на дугме $X$, проведено вријеме се рачуна као 0 секунди, без обзира на то што је можда на страници провео 10 или 20 минута, а са̂м улазак на страницу се ипак региструје као посјета. Вријеме „тече“ само ако са једне странице оде на другу. Та погрешно смањена просјечна вриједност потврђује се и високом стопом посјете само једној страници (75,34\%), што се може видјети на сљедећем исјечку из годишњег графикона. Укупно трајање сесија у протеклој години је 3276 минута, од чега су 33 трајања преко пола сата, а 61 у распону између 10 и 30 минута.

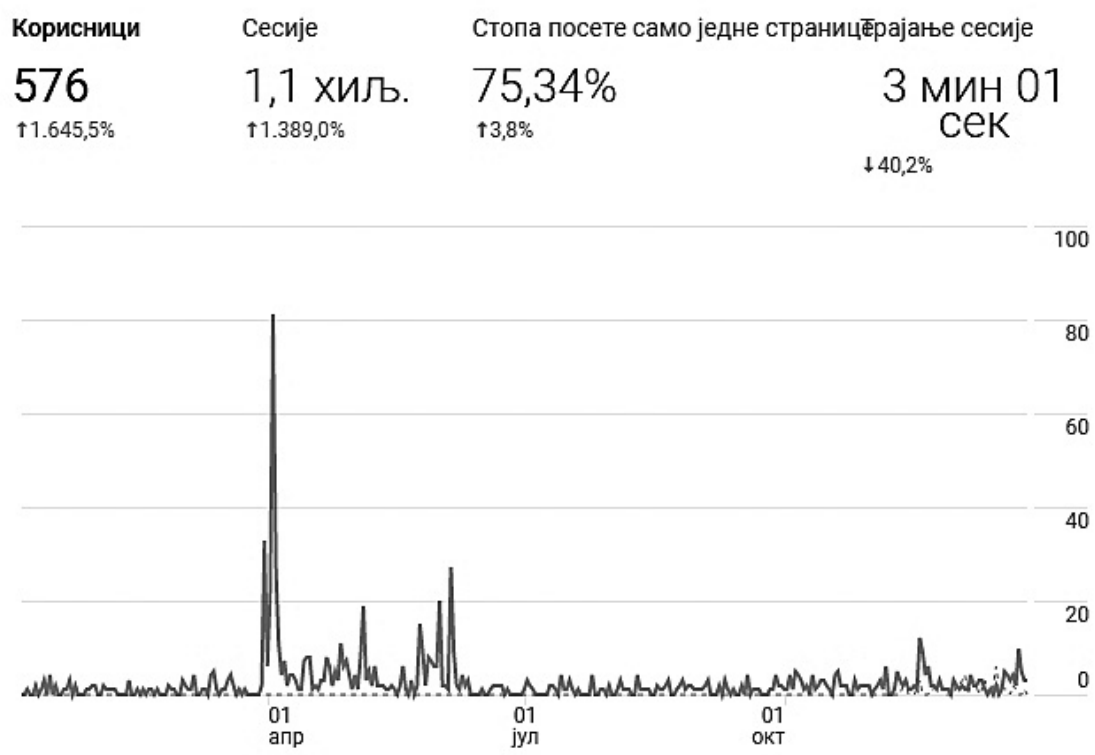

Слика 2

За базу података као што је Дигитална библиотека, врсту веб-мјеста које нема висок саобраћај, већ је креирано да се развија и постане извор информација са архивском сврхом, оваква основна статистичка анализа не може рећи превише, барем не у кратком временском периоду, можда тек уколико би се кориснички промет пратио кроз деценију рада и развоја. Међутим, и на овако малом узорку, сљедећи графикон указује на нека већ сада прилично уочљива правила.

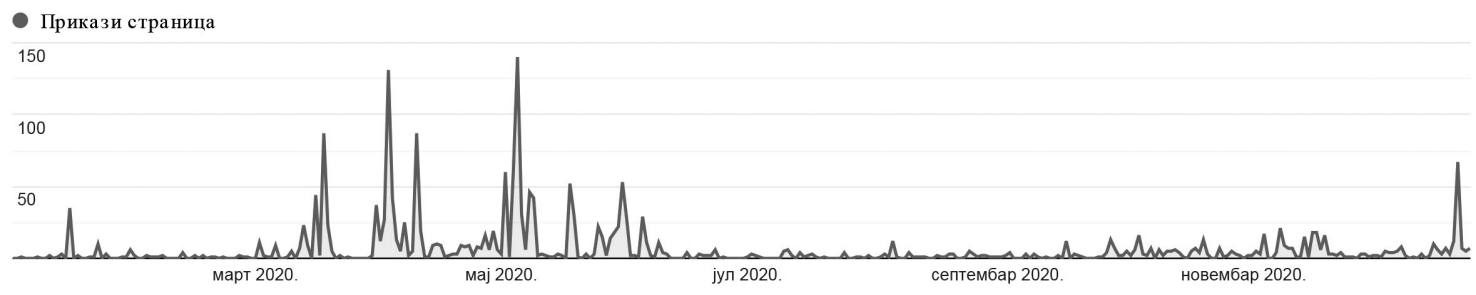

Слика 3 
Графикон показује број прегледа страница у посматраном периоду. Осим активности која је ниска, али непрекинута и стабилна, могу се уочити нагли скокови. Да би се пронашли узроци тих изненадних промјена, неопходно је податке које обезбјеђује овај алат комбиновати са подацима из других извора (друштвене мреже, Јутјуб, РТВ Будва, интерни подаци Библиотеке). Сви скокови се поклапају са појачаним активностима Библиотеке на друштвеним мрежама и гостовањима на локалној телевизији - обиљежавања важних датума, иницијативе током пандемије вируса КОВИД-19, онлајн промоције сопствених издања.

Овако јасан утицај медија, упркос спорадичном присуству ДББ у њима, а нарочито утицај активности на Фејсбуку, јасно указује да су ово важни фактори за креирање канала којима ће корисници доћи до њених дигиталних колекција. Канал који статистика у свим пресјецима избацује као најважнији управо је промет са друштвених мрежа. Ако се узме у обзир да је Народна библиотека Будве активна само на Фејсбуку (и то на начине који доприносе повећању промета на ДББ само током два периода у 2020. години), можда би требало размотрити активирање профила на другим друштвеним мрежама (Инстаграм, на којем борави млађа популација, на примјер), али и појачати присуство у медијима ван локалних оквира.

\section{Ко разумије данас, може да планира одрживо сутра}

Уз ограничено владање аутора специфичним знањима вебометрије и без обзира на недостатке изабраног истраживачког алата, добијени налази су много детаљнији од било чега што се може добити традиционалним методама библиотечке статистике.

Област истраживања и анализе података о инвестицијама библиотека у веб-платформе је веома актуелна јер пружа чињенична и мјерљива образложења за уложене напоре и средства и позиционира библиотеке као активне чиниоце у дигиталној парадигми коју карактерише крилатица from collection to connection ${ }^{6}$ : окренутост човјеку, а не простору; корисницима и повећању корисничке партиципације, а не магацинима и повећању броја пуних полица у њима. О том значају свједочи убрзање динамике издавања Међународног ISO стандарда 2798 - Meђународна библиотечка статистика почетком 21. вијека, управо због проширења стандарда у дијелу електронских услуга библиотека. Цијели Прилог А стандарду, који је нормативан, носи наслов „Мјерење коришћења електронских сервиса библиотеке“.

О растућем значају располагања подацима о коришћењу дигитализованих садржаја свједочи и промјена у тачки посматрања и структури међународних анкета. У великом и детаљном (82 питања) истраживању „Преглед дигитализације и дугорочног очувања“, 8 које је 1998-1999. године урадила IFLA (International Federation of Library Organizations - IFLA) у сарадњи са UNESCO-м (United Nations Educational, Scientific and Cultural Organization - UNESCO), на основу анкете послате у 150 националних библиотека свијета, није било ниједног питања о корисницима дигиталних библиотека, већ само одјељак о техничким карактеристикама приступа. Само пет година касније, пројекат ENUMERATE, који је финансирала Европска комисија кроз програм ICT PSP (ICT Policies Support Programme - Програм подршке ИКТ политикама), резултирао је извјештајем ${ }^{9}$ за Комисију о стању дигитализације у европским институцијама културне баштине. У њему једна група питања носи наслов „Мјерење коришћења дигиталних колекција“ и обухвата прикупљање података на четири различита начина. Пионирско домаће

\footnotetext{
${ }^{6}$ Diederick Slijkerman and Ton van Vlimmeren, eds., Living Libraries (Utrecht: Bibliotheek Utrecht, 2021$), 15$.

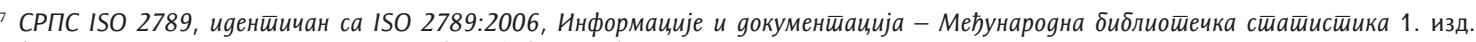
(Београд: Институт за стандардизацију Србије, 2008).

8 Sara Gould et al., IFLA/UNESCO survey on digitisation and preservation (Wetherby, England: IFLA Offices for UAP and International Lending, 1999), preuzeto 14. 1. 2021, https://www.ifla.org/files/assets/pac/ipi/ipi2\%20vers2.pdf.

${ }^{9}$ N. Stroeker and R. Vogels, "ENUMERATE Survey Report on Digitisation in European Cultural Heritage Institutions 2014", Europeana, preuzeto 14. 1. 2021, https://pro.europeana.eu/files/Europeana_Professional/Projects/Project_list/ENUMERATE/other_documentation/ENUMERATE-Digitisation-Survey-2014.pdf.
} 
истраживање, "Дигитализација библиотека у Црној Гори“, поред исцрпне фактографске слике стања дигитализације у библиотекама у овој држави, питања коришћења не обрађује детаљније јер нису обухваћена пројектним задатком. ${ }^{10}$

Статистика је моћан преговарачки капитал у односу према оснивачима, финансијерима и другим релевантним друштвеним чиниоцима са којима једна библиотека стоји у односу. Међутим, она је то само ако се изводи и презентује другачије него „статистика - наша дика“: на основу чињеничних, мјерљивих и провјерљивих података; јасних и јавно доступних стандардизованих процедура и логичних закључака и смјерница који произилазе из статистичких налаза.

Статистика је, такође, сировина за више управљачке процесе: за извођење показатеља учинка библиотека и формулисање развојних стратегија. Она омогућава да библиотека тежиште стави на одређене сегменте и начине рада, одлучујући на основу чињеница, а не утисака и неструктурисаних искуствених ставова.

На основу добијених података у овом истраживању, различите дијелове анализе прате коментари, а као општи закључци и, истовремено, елементи за стратегију развоја, намећу се: проширивање понуде дигиталних садржаја визуелном грађом - која одговара интересовањима и корисничким навикама доминанатне публике ДББ, популаризовање ДББ на мјестима стручне и научне комуникације - са циљем продужавања трајања корисничких сесија те веће присуство у медијима и на друштвеним мрежама - које директно узрокује повећање броја посјета. Побољшање резултата у ове три области допринијело би оправдању разлога за стварање ДББ: увођење онлајн понуде примарних документационих извора и циљева који су постављени на почетку: повећање броја корисника, стицање редовних корисника, продужење трајања сесија са дББ, повећање броја преузимања дигиталних јединица.

\section{Литература и извори:}

1. Đurović, Jelena, „Digitalizacija biblioteka u Crnoj Gori“. Rad predstavljen na Digitalizacija u Crnoj Gori: istorijat, stanje i perspektiva, Podgorica, Crna Gora, 27.9.2019.

2. Google Analytics Academy. Preuzeto 20. 12. 2020. https://analytics.google.com/analytics/academy/ course/6.

3. Gould, Sara et al. IFLA/UNESCO survey on digitisation and preservation. Wetherby, England: IFLA Offices for UAP and International Lending, 1999. Preuzeto 14. 1. 2021. https://www.ifla.org/files/assets/pac/ ipi/ipi2\%20vers2.pdf.

4. Luketić, Miroslav. „Prilog proučavanju narodnog bibliotekarstva u budvanskoj opštini“. U Kulturna baština I, 409-415. Budva: JU Narodna biblioteka Budve, 2019.

5. Ljubanović, Gordana i Maja Simonović. „Digitalna Narodna biblioteka Budve“. Škver 4 (2020), 5 (2021, u pripremi). Preuzeto 20. 1. 2021.http://skvermagazin.me/.

6. Narodna bibioteka Budve. Preuzeto 21. 12. 2020. https://www.nbbd.me.

7. Rowlands, I., D. Nicholas, P. Williams, P. Huntington, M. Fieldhouse, B. Gunter, R. Withey, M. Hamid, R., Jamali, T. Dobrowolski and C. Tenopir. "The Google generation: the information behaviour of the researcher of the future." Aslib Proceedings 60 (2008): 290-310.

8. Slijkerman, Diederick and Ton van Vlimmeren, eds. Living Libraries. Utrecht: Bibliotheek Utrecht, 2021.

9. SRPS ISO 2789, identičan sa ISO 2789:2006, Informacije i dokumentacija-Međunarodna bibliotečka statistika. 1. izd. Beograd: Institut za standardizaciju Srbije, 2008.

\footnotetext{
10 Јелена Ђуровић, „Дигитализација библиотека у Црној Гори“ (рад представљен на Дигитализација у Црној Гори: историјат, стање и перспектива, Подгорица, Црна Гора, 27. 9. 2019).
} 
10. Stroeker, N. and R. Vogels. "ENUMERATE Survey Report on Digitisation in European Cultural Heritage Institutions 2014". Europeana. Preuzeto 14. 1. 2021. https://pro.europeana.eu/files/Europeana_Professional/Projects/Project_list/ENUMERATE/other_documentation/ENUMERATE-DigitisationSurvey-2014.pdf.

\section{Users and Usage of the Digital Library of Budva}

\section{Summary}

In 2018, the Public Library of Budva decided to start building a digital library with the desire to expand the existing offer of online services and meet the needs of the modern audience that is increasingly using digital content. Sometime after launching the Digital Library of Budva (DLB) in November 2019, two issues naturally have raised, asking for evidence-based answers: the effectiveness of invested resources and the direction of the further development. Although the content is locally oriented, the hypothesis was that this new channel of presentation would attract audiences from a far wider geographical area. This hypothesis is confirmed, as well as the empirical observations that there is a direct and high correlation between the number of sessions and presence at social and other media, and that users are inclined to access the DLB via mobile devices, behaving more like sightseers than attentive readers. The analysis of web traffic during one year was performed using Google Analytics.

The main aim of the analysis was to get a clear insight into the structure, interests, and behavior of users. It was supposed to be a base for achieving all the defined goals - increasing the number of users, acquiring regular users, extending sessions, and increasing the number of digital unit downloads. Despite limitations in the author's specific knowledge of webometrics and the possibilities of Google Analytics, and the short period that was being analyzed, the results and conclusions are valuable for determining the main directions of the future DLB development policy. The analysis has shown three main areas as the most important to pay attention to - expanding the offer of digital content with visual materials, a greater presence in the media and on social networks, and popularization of DLB in places of professional and scientific communication. Achieving better results in these three areas would help justify all the mentioned reasons for creating the Digital Library.

Keywords: Public Library of Budva, Digital Library of Budva, digital libraries, online library services, quantitative surveys, statistical analysis of library users, statistical analysis of library usage, Google Analytics, webometrics, social networks 